\title{
Microwave Plasma Gasification Performance of Sawdust
}

\author{
Aytaç ŞANLISOY, Melda Ö. ÇARPINLIOĞLU \\ *Faculty of Engineering, Department of Mechanical Engineering, Gaziantep University, Turkey
}

\begin{abstract}
In this study, the gasification performance of the pine tree sawdust and hornbeam sawdust at varied microwave plasma power is investigated. In each case, $250 \mathrm{~g}$ sawdust are dosed to gasification reactor. The effects of power on syngas composition and reactor temperature are studied. The sawdust contents are examined by ultimate and proximate analysis. The heating value of the fuels are measured as 21353 $\mathrm{kJ} / \mathrm{kg}$ for hornbeam sawdust and $17942 \mathrm{~kJ} / \mathrm{kg}$ for pine tree sawdust by bomb calorimeter. The syngas content is substantially proportional with the content of the fuel. The variation of local temperatures during the gasification is of great importance on the process. The temperature is increased by increasing the power and the conversion performance of sawdust is enhanced. The temperature in gasifier increase $\% 54$ in case by increasing power from $3 \mathrm{~kW}$ to $6 \mathrm{~kW}$. $\mathrm{CO}, \mathrm{CH}_{4}$ and $\mathrm{H}_{2}$ conversion increase by increasing the power while $\mathrm{CO}_{2}$ conversion decreases by power.
\end{abstract}

Key words: Sawdust, gasification, plasma, microwave

\section{Introduction}

There are variety of methods to convert the biomass into fuel or energy [1]. One of this method is the gasification of biomass into syngas. In this method, the biomass gasified by absence or oxygen starved media and converted to syngas by partial oxidizations. While the gasification process is a known old process, the process is further improved by using the plasma as heater. By gasification, the biomass decomposed to its components and mainly $\mathrm{CO}, \mathrm{H}_{2}, \mathrm{CO}_{2}$ and simple hydrocarbons [2]. There are several methods to gasify the matters such as depending on reactor type; updraft or downdraft fixed bed, bubbling or circulating fluidized bed, depend on power supply; allo-thermal and auto-thermal process, depending on reaction media; pyrolysis and gasification [3]. The increase of gasifier temperature enhances the conversion of fuel. The plasma gasification method has unique advantages of very high temperature, high response, simple and compact design in comparison with other methods [4]. In this study, the effects of power and air flow rate on gasification performance of hornbeam and pine tree sawdust are investigated. The temperature distribution in the reactor is revealed and the conversion characteristics are examined.

*Corresponding author: Aytaç Şanlısoy Address: Faculty of Engineering, Department of Mechanical Engineering, Gaziantep University, Turkey. E-mail address: aytacsanlisoy@gmail.com, Phone: +903423171591 


\section{Materials and Method}

Microwave plasma gasification system MCw Gasifier (Figure 1) consists of the following subcomponents; Microwave plasma system, solid waste feeding and fluid supply systems, gasification reactor, process outputs collection system and the measurement - data acquisition system. The experimental system explanation is also given in the authors papers $[5,6]$, thesis of the first author [7] and project of authors [8].

\subsection{Microwave Plasma System}

In microwave plasma system, the generation and transfer of the microwave signal to the reactor are performed. Microwave plasma gasification system consists of Power supplier, magnetron, isolator, stub-tuner, and waveguide and plasma applicator for the plasma. Here the products were purchased from MUEGGE Company which is based on the study of Martin Leins [9].

\subsection{Gasification Reactor}

Gasification reactor consists of two parts. The first part is the reduction part comprising the head of the reactor where the diameter is reduced for the interaction of the solid waste by plasma. The other part is the main body of the reactor. The main part is formed of $81 \mathrm{~mm}$ inner diameter stainless steel pipe which has $3 \mathrm{~mm}$ thickness and $500 \mathrm{~mm}$ height.

\subsection{Fluid (Air) Supply System}

The required air flow rate is obtained by using Lupamat LKV 30/8 model screw compressor. It generate compressed air which has 8 bar pressure and $4850 \mathrm{~L} / \mathrm{min}$ flow rate. The required pressure and flow rate are adjusted by using pressure regulator.

\subsection{Flow (Air) Measurement System}

The air flow rate is measured by ALICAT MCR-250 L/min-D model mass flow controller. The required air flow rate for plasma applicator varies from 0 to $200 \mathrm{~L} / \mathrm{min}$.

\subsection{Measurement of Reactor Temperature}

The thermocouples which are located at measurement positions along the reactor length in the flow direction of plasma. The first measurement location from plasma applicator's edge is $175 \mathrm{~mm}$ away because of the extreme high temperature of the plasma. The location of the thermocouples are $y / h=0.28,0.44,0.6,0.76$ and 0.92 . The height $(h)$ of the reactor which begin from the applicator to the end of the main reactor is $625 \mathrm{~mm}$. 5 thermocouples are located along the axis of the pipe with $100 \mathrm{~mm}$ intervals. The B type (Pt18Rh-Pt) thermocouples are used with pure alumina coating. Their measuring abilities are the temperatures up to $1820^{\circ} \mathrm{C}$ with an accuracy of $\pm 4{ }^{\circ} \mathrm{C}$. 
The thermocouple sensing edges are immersed at $40 \mathrm{~mm}$ perpendicular to the reactor wall such that the measurement inside the plasma flame is possible. The measured inputs are recorded via Elimko E-PR-110 model data acquisition card. The temperature measurements are recorded with 1 second sampling period.

\subsection{Gas analyzing system for the syngas}

MRU-Various plus model syngas monitoring system is used to determine the syngas content. It provides continuous syngas monitoring of the process. It can measure the syngas content of $\mathrm{CO}$, $\mathrm{CO}_{2}, \mathrm{CH}_{4}, \mathrm{H}_{2}$, and $\mathrm{N}_{2}$ up to $100 \%$ and $\mathrm{O}_{2}$ up to $25 \%$. It uses the nondispersive infrared sensors to measure the $\mathrm{CO}, \mathrm{CO}_{2}$ and $\mathrm{CH}_{4}$ while it uses the thermal conductive detector and electrical conductive sensor to measure the $\mathrm{H}_{2}$ and $\mathrm{O}_{2}$ respectively. It has $1 \%$ linearity and repeatability error. It has also $\% 2$ span drift and $0.05 \%$ detection limit. The measurements are recorded by the device which is connected to computer to monitor and data acquisition. The sampling frequency is adjusted to 2 seconds. The system records the gas composition continuously. The process time is determined from the gas composition changes at the beginning and end of the process.

\section{Results}

In this study, the hornbeam sawdust and pine tree sawdust are taken as fuel for the plasma gasification. The gasification results of sawdust is taken from thesis of the first author [7]. The proximate and ultimate analysis methods; heating value evaluations and the results of these fuels are explained in detail in the study authors [10].

The temperature distribution at powers between $3 \mathrm{~kW}$ and $6 \mathrm{~kW}$, for fuels; pine tree and hornbeam sawdust and $50 \mathrm{sL} / \mathrm{min}$ air flow rate is presented in Figure 3. The temperature in the reactor reduces from plasma flame to the upward. The temperature increases by increasing the plasma power. The temperature reduces from plasma flame to upward from $921{ }^{\circ} \mathrm{C}$ to $515{ }^{\circ} \mathrm{C}$ at $3 \mathrm{~kW}, 950{ }^{\circ} \mathrm{C}$ to 579 ${ }^{\circ} \mathrm{C}$ at $3.6 \mathrm{~kW}, 1046^{\circ} \mathrm{C}$ to $657{ }^{\circ} \mathrm{C}$ at $4.2 \mathrm{~kW}, 1184^{\circ} \mathrm{C}$ to $712^{\circ} \mathrm{C}$ at $4.8 \mathrm{~kW}, 1349{ }^{\circ} \mathrm{C}$ to $786{ }^{\circ} \mathrm{C}$ at 5.4 $\mathrm{kW}$ and $1476{ }^{\circ} \mathrm{C}$ to $825^{\circ} \mathrm{C}$ at $6 \mathrm{~kW}$ in case of hornbeam sawdust gasification. The temperature reduces from plasma flame to upward from $937{ }^{\circ} \mathrm{C}$ to $516^{\circ} \mathrm{C}$ at $3 \mathrm{~kW}, 951{ }^{\circ} \mathrm{C}$ to $578{ }^{\circ} \mathrm{C}$ at $3.6 \mathrm{~kW}$, $1047{ }^{\circ} \mathrm{C}$ to $651{ }^{\circ} \mathrm{C}$ at $4.2 \mathrm{~kW}, 1205^{\circ} \mathrm{C}$ to $714^{\circ} \mathrm{C}$ at $4.8 \mathrm{~kW}, 1361{ }^{\circ} \mathrm{C}$ to $779{ }^{\circ} \mathrm{C}$ at $5.4 \mathrm{~kW}$ and 1447 ${ }^{\circ} \mathrm{C}$ to $818^{\circ} \mathrm{C}$ at $6 \mathrm{~kW}$ in case of pine tree sawdust gasification. The average syngas temperature increases by increasing plasma power from $3 \mathrm{~kW}$ to $6 \mathrm{~kW}$ from $759{ }^{\circ} \mathrm{C}$ to $1175{ }^{\circ} \mathrm{C}$ in case of hornbeam sawdust gasification and from $766^{\circ} \mathrm{C}$ to $1169^{\circ} \mathrm{C}$ in case of pine tree sawdust gasification. 

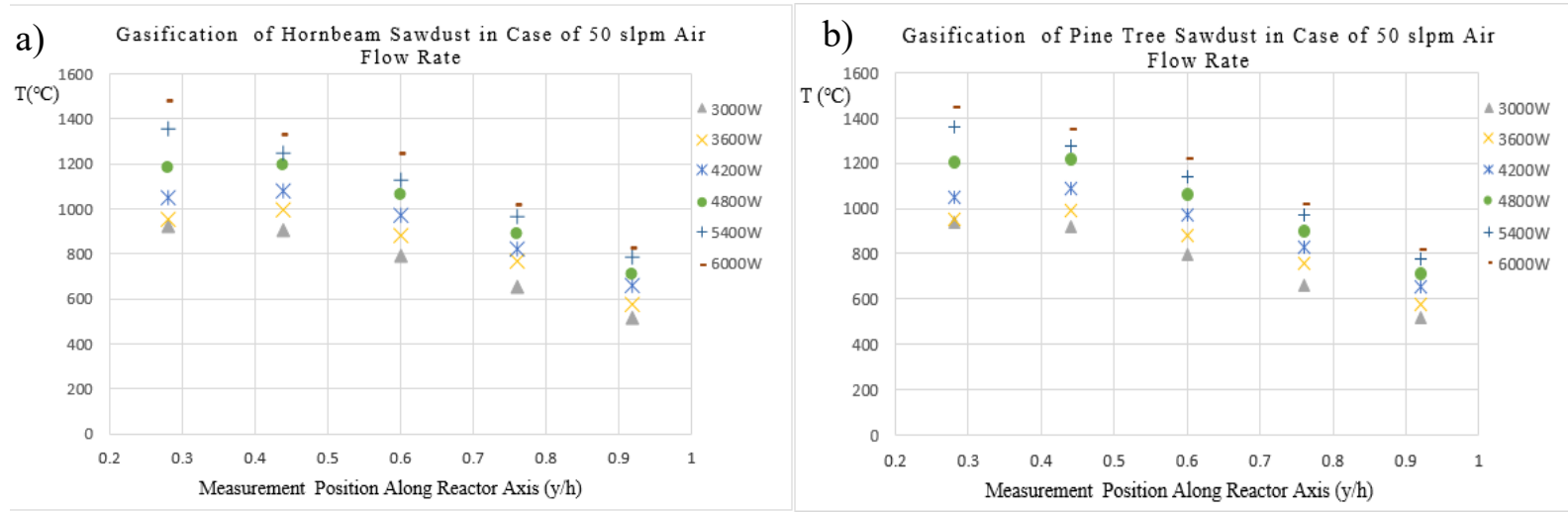

Figure 3. Temperature distribution in the reactor depending on power, air flow rate and sawdust type

The content of syngas in molar base is presented in case of gasification of hornbeam sawdust and pine tree sawdust at power levels between $3 \mathrm{~kW}$ and $6 \mathrm{~kW}$ in Table 2 . The fractions of syngas in case of gasification of hornbeam sawdust (HSD) at power levels between $3 \mathrm{~kW}-6 \mathrm{~kW}$ are presented in first row. As a result of the process, the $\mathrm{O}_{2}$ in syngas stays below $0.9 \%$ in all power levels. The $\mathrm{CO}_{2}$ gradually decreases by increasing power from $16.79 \%$ at $3 \mathrm{~kW}$ to $10.49 \%$ at $6 \mathrm{~kW}$. In contrast to that, the $\mathrm{CO}$ and $\mathrm{H}_{2}$ increase by increasing the power. The $\mathrm{CO}$ increases from $7.33 \%$ to 18.95 $\%$ and $\mathrm{H}_{2}$ increases from $2.35 \%$ to $8.65 \%$ by increasing power from $3 \mathrm{~kW}$ to $6 \mathrm{~kW}$. The $\mathrm{CH}_{4}$ stays in the level of $1.8 \%$ in all power cases. The rest of the mixture is considered as $\mathrm{N}_{2}$ that reduces by increase of power from $70.97 \%$ to $59.22 \%$.

Table 2. Syngas distribution depending on power, air flow rate and type of sawdust

\begin{tabular}{|c|c|c|c|c|c|c|c|}
\hline Fuel type & & \multicolumn{7}{|c|}{ Syngas distribution } \\
\hline \multirow{4}{*}{ Hornbeam sawdust } & Power (W) & $\mathbf{O 2 , \%}$ & $\mathbf{C O 2 , \%}$ & $\mathbf{C O , \%}$ & $\mathbf{H 2 , \%}$ & $\mathbf{C H 4 , \%}$ & $\mathbf{N 2 , \%}$ \\
\cline { 2 - 8 } & 3000 & 0.68 & 16.79 & 7.33 & 2.35 & 1.87 & 70.97 \\
\cline { 2 - 8 } & 3600 & 0.77 & 13.80 & 8.97 & 4.43 & 1.83 & 70.19 \\
\cline { 2 - 8 } & 4200 & 0.81 & 11.34 & 9.23 & 5.12 & 1.81 & 71.69 \\
\cline { 2 - 8 } & 4800 & 0.69 & 11.28 & 14.2 & 5.63 & 1.83 & 66.37 \\
\cline { 2 - 8 } & 5400 & 0.83 & 10.89 & 15.27 & 6.87 & 1.8 & 64.34 \\
\cline { 2 - 8 } & 6000 & 0.88 & 10.49 & 18.95 & 8.65 & 1.81 & 59.22 \\
\hline \multirow{5}{*}{ Pine tree sawdust } & Power (W) & $\mathbf{O 2 , \%}$ & $\mathbf{C O 2 , \%}$ & $\mathbf{C O , \%}$ & $\mathbf{H 2 , \%}$ & $\mathbf{C H 4 , \%}$ & $\mathbf{N 2 , \%}$ \\
\cline { 2 - 8 } & 3000 & 0.82 & 18.20 & 8.30 & 3.20 & 2.17 & 67.31 \\
\cline { 2 - 8 } & 3600 & 0.86 & 15.91 & 8.88 & 4.30 & 2.13 & 67.92 \\
\cline { 2 - 8 } & 4200 & 0.85 & 14.87 & 9.69 & 5.6 & 2.21 & 66.78 \\
\cline { 2 - 8 } & 4800 & 0.88 & 13.19 & 12.7 & 5.84 & 2.28 & 65.11 \\
\cline { 2 - 8 } & 5400 & 0.91 & 11.27 & 14.82 & 6.21 & 2.25 & 64.54 \\
\cline { 2 - 8 } & 6000 & 0.90 & 10.22 & 17.35 & 8.98 & 2.23 & 60.33 \\
\hline
\end{tabular}

The distribution of syngas content by changing power in case of gasification of pine tree sawdust (PSD) at $50 \mathrm{sL} / \mathrm{min}$ air flow rate and power levels between $3-6 \mathrm{~kW}$ is shown in last row of Table 2. As a result of the process, the $\mathrm{O}_{2}$ in syngas stay below $0.91 \%$ in all power levels. The $\mathrm{CO}_{2}$ gradually goes down by increasing power from $18.20 \%$ at $3 \mathrm{~kW}$ to $10.22 \%$ at $6 \mathrm{~kW}$ although the 
$\mathrm{CO}$ and $\mathrm{H}_{2}$ rise by increasing the power. The $\mathrm{CO}$ and $\mathrm{H}_{2}$ go up from $8.30 \%$ to $17.35 \%$ and from $3.2 \%$ to $8.98 \%$ respectively by increasing power from $3 \mathrm{~kW}$ to $6 \mathrm{~kW}$. The $\mathrm{CH}_{4}$ varies between $2.13 \%$ and $2.28 \%$. The remainder of the syngas, $\mathrm{N}_{2}$ reduces from $67.31 \%$ to $60.33 \%$ by increment of power from $3 \mathrm{~kW}$ to $6 \mathrm{~kW}$.

\section{Conclusions}

In this study, the effects of power and types of sawdust on plasma gasification process are examined. The temperature and syngas content distribution are measured continuously during the process. The magnitude of the temperature in the reactor increases by increasing the power. The conversion performance of sawdust is enhanced by increasing the power. The temperature in gasifier increases \% 54 by increasing power from $3 \mathrm{~kW}$ to $6 \mathrm{~kW}$. CO, $\mathrm{CH}_{4}$ and $\mathrm{H}_{2}$ conversion is increased by increasing the power while $\mathrm{CO}_{2}$ conversion is decreased by increasing power.

\section{Acknowledgements}

The authors would like to acknowledge the financial support of this work by the Scientific and Technological Research Council of Turkey (TUBITAK) under the contract number 115M389. Also, authors are thankful for the financial support of University of Gaziantep BAP -RM16.01.

\section{References}

[1] Leckner B. Process aspects in combustion and gasification Waste-to-Energy (WtE) units. Waste Management 2015:37:13-25.

[2] Gray L, Plasma Gasification as a Viable Waste-to-Energy Treatment of Municipal Solid Waste. 2014, Solid and Hazardous Waste Prevention and Control Engineering: Hartford, USA. p. $1-15$.

[3] Tang L, Huang H, Hao H, Zhao K. Development of Plasma Pyrolysis/Gasification Systems for Energy Efficient and Environmentally Sound Waste Disposal. Journal of Electrostatics 2013:71:839-47.

[4] Shie J-L, Chen L-X, Lin K-L, Chang C-Y. Plasmatron gasification of biomass lignocellulosic waste materials derived from municipal solid waste. Energy 2014:66:82-9.

[5] Sanlisoy A, Carpinlioglu MO, Presentation of a Microwave Plasma Gasification System "MCw Gasifier" in Fourth European Conference on Renewable Energy Systems (ECRES2016). 2016: Istanbul. p. 503-6.

[6] Sanlisoy A, Carpinlioglu MO. Preliminary measurements on microwave plasma flame for gasification. Energy, Ecology and Environment 2017:

[7] Sanlisoy A, An Experimental Investigation on Design and Performance of Plasma Gasification Systems, in Mechanical Engineering Department of Gaziantep University. 2018, Gaziantep University. 
[8] Çarpınlıoğlu MÖ. Katı Atıkların Enerji Dönüşümünde Plazma Gazlaştırma Kullanımı ile Çalışan Laboratuvar Ölçekli Bir Test Düzeneğinin (Mikrodalga Gazlaştırıcı) "Mcwgazlaştırıcı" Tasarım Üretim ve Performans Değerlendirilmesi-Plazma Gazlaştırma Teknolojisinin-Bilginin Üretilip Kullanılmasında Bir Vaka TUBITAK 115M389 final report 2018:

[9] Leins M, Alberts L, Kaiser M, Walker M, Schulz A, Schumacher U, Stroth U. Development and Characterisation of a Microwave-heated Atmospheric Plasma Torch. Plasma Processes and Polymers 2009:6:S227-S32.

[10] Sanlisoy A, Melez H, Carpinlioglu MO. Characteristics of the Solid Fuels for the Plasma Gasification. Energy Procedia 2017:141:282-6. 